R. D. Ramracheya - D. S. Muller $\cdot$ Y. Wu $\cdot$

B. J. Whitehouse - G. C. Huang - S. A. Amiel •

J. Karalliedde - G. Viberti - P. M. Jones - S. J. Persaud

\title{
Direct regulation of insulin secretion by angiotensin II in human islets of Langerhans
}

Received: 19 July 2005 / Accepted: 6 October 2005 / Published online: 17 January 2006

C) Springer-Verlag 2006

\begin{abstract}
Aims/hypothesis: This study aimed to identify the expression of angiotensin II receptors in isolated human islets and beta cells and to examine the functional consequences of their activation. Materials and methods: Singlecell RT-PCR was used to identify whether human islet cells express mRNA for type 1 angiotensin II receptors $\left(\mathrm{AT}_{1}\right)$, and western blotting was used to determine $\mathrm{AT}_{1}$ protein expression by human islets and MIN6 beta cells. We measured changes in intracellular calcium by microfluorimetry using Fura 2-loaded MIN6 cells and human islet cells. Dynamic insulin secretory responses were determined by RIA following perifusion of human islets and MIN6 cells. Results: Human islets expressed mRNAs for both the angiotensin precursor, angiotensinogen, and for angiotensin-converting enzyme. In addition, human and mouse beta cells expressed $\mathrm{AT}_{1}$. These were functionally coupled to increases in intracellular calcium, which occurred at least in part through phospholipase-C-sensitive mechanisms and calcium influx through voltage-operated calcium channels.
\end{abstract}

R. D. Ramracheya · D. S. Muller · Y. Wu · B. J. Whitehouse

P. M. Jones · S. J. Persaud $(\bowtie)$

Beta Cell Development and Function Group,

Division of Reproductive Health, Endocrinology

and Development, King's College London,

Room 2.9N Hodgkin Building Guy's Campus,

London SE1 1UL, UK

e-mail: shanta.persaud@kcl.ac.uk

Tel: $+44-20-78486275$

Fax: +44-20-78486280

G. C. Huang · S. A. Amiel

Division of Gene and Cell Based Therapy,

King's College London,

London, UK

J. Karalliedde $\cdot$ G. Viberti

Cardiovascular Division, King's College London,

London, UK

R. D. Ramracheya

Oxford Centre for Diabetes, Endocrinology and Metabolism, University of Oxford,

Oxford, UK
Short-term exposure of human islets and MIN6 cells to angiotensin II caused a rapid, short-lived initiation of insulin secretion at $2 \mathrm{mmol} / \mathrm{l}$ glucose and potentiation of insulin secretion induced by glucose (at 8 and $16.7 \mathrm{mmol} / \mathrm{l}$ ). Conclusions/interpretation: These data demonstrate that the $\mathrm{AT}_{1}$ is expressed by beta cells and that angiotensin II effects a short-lived and direct stimulation of human and mouse beta cells to promote insulin secretion, most probably through elevations in intracellular calcium. Locally produced angiotensin II may be important in regulating a coordinated insulin secretory response from beta cells.

Keywords Angiotensin II - Calcium microfluorimetry · Human islets · Insulin secretion · MIN6 cells

Abbreviations AGT: Angiotensinogen - Ang II: Angiotensin II $\cdot \mathrm{AT}_{1}$ : Type 1 Ang II receptor $\cdot$ $\mathrm{AT}_{2}$ : Type 2 Ang II receptor $\cdot\left[\mathrm{Ca}^{2+}\right]_{\mathrm{i}}$ : Intracellular calcium concentration - HT: Hypertensin $\cdot \mathrm{IP}_{3}$ : Inositol trisphosphate - PLC: Phospholipase C - RAS: Reninangiotensin system

\section{Introduction}

Due to its vasoconstrictive effects, the systemic reninangiotensin system (RAS) is classically linked to the regulation of blood pressure and fluid and electrolyte balance [1]. The systemic RAS is composed of several components including the precursor angiotensinogen (AGT), angiotensin II (Ang II) and multiple receptor subtypes [2], linked by alternative, non-exclusive components such as the enzymes renin and ACE $[3,4]$. Ang II induces its effects via at least two G-protein-coupled transmembrane receptors, Ang II receptor $1\left(\mathrm{AT}_{1}\right)$ and Ang II receptor $2\left(\mathrm{AT}_{2}\right)$, of which the former is considered to be more physiologically important. Thus, $\mathrm{AT}_{1}$ receptors are expressed abundantly in many adult tissues, but expression is limited in neonatal tissues [1], whereas $\mathrm{AT}_{2}$ receptors are widely expressed in embryonic and neonatal tissues, but only in a few adult tissues $[5,6]$. 
There is evidence of local angiotensin-generating systems in several organs, including the brain, pituitary, heart, kidney, gonads and pancreas (see [7]). An intrinsic pancreatic angiotensin-generating system was demonstrated in the canine pancreas $[8,9]$ by localisation of mRNA and protein for AGT and Ang II receptors, and subsequent studies have identified RAS components in rat, mouse and primate pancreas $[7,10,11]$. The highest densities of pancreatic Ang II receptors are reported to be localised to pancreatic ducts, vascular endothelium and acinar cells [10]. Although it has recently been reported that $\mathrm{AT}_{1}$ receptors are localised to mouse pancreatic beta cells [11], there is currently no direct evidence of $\mathrm{AT}_{1}$ receptor expression by human islet beta cells, nor of the effect of exogenous Ang II on human islet function.

The existence of an intrinsic pancreatic RAS may have pathophysiological implications, since type 2 diabetes is often associated with essential hypertension $[12,13]$, and hypertension is a significant risk factor for the development of type 2 diabetes [13]. Moreover, there is some evidence that ACE inhibition or Ang II receptor blockade protects from the development of glucose intolerance in hypertensive patients [14-16], and experimental manipulation of systemic RAS in humans can influence insulin secretory responses [14-17]. However, it is difficult for in vivo studies or experiments using the whole pancreas to differentiate between effects on the pancreatic vasculature and direct effects on islet endocrine function, and the inhibitory effects of Ang II on insulin release in vivo or in the perfused pancreas have been attributed to its vasoconstrictive effects on islet blood flow $[18,19]$.

Studies using isolated islets or beta cells avoid the complications of vascular effects of RAS activation, but have produced conflicting results in rodent models, in which inhibitory effects [11] and the absence of any effect [20] on hormone secretion have been reported. In the present study we therefore used human islets, isolated human beta cells and a mouse beta cell line to investigate the expression of Ang II receptors and the functional consequences of their activation.

\section{Subjects, materials and methods}

Isolation and maintenance of human islets of Langerhans

Human islets were obtained from the King's College Hospital Islet Transplantation Unit (King's College Hospital, London, UK). Briefly, islets were isolated from multiorgan donors using novel density gradient media [21] after donors' relatives had specifically consented to the use of their relatives' pancreases for islet research, in the event that it was not used for clinical transplantation. This study was approved by the Ethics Committee of King's College Hospital NHS Trust. Over $90 \%$ of islets isolated by this procedure are viable and show purities of between 80 and $95 \%$ [21]. Islets were maintained $\left(5 \% \mathrm{CO}_{2}\right)$ in CMRL culture medium supplemented with $10 \% \mathrm{FCS}$, and
$100 \mathrm{U} / \mathrm{ml}$ penicillin $/ 0.1 \mathrm{mg} / \mathrm{ml}$ streptomycin for up to 3 days prior to experimental use, and they were then further purified under a dissecting microscope using a finely drawn capillary pipette.

\section{Maintenance of MIN6 cells}

MIN6 insulin-secreting cells were maintained at $37^{\circ} \mathrm{C}(5 \%$ $\mathrm{CO}_{2}$ ) in DMEM supplemented with $10 \% \mathrm{FCS}, 2 \mathrm{mmol} / 1$ glutamine and $100 \mathrm{U} / \mathrm{ml}$ penicillin with $0.1 \mathrm{mg} / \mathrm{ml}$ streptomycin. The medium was changed every 3 days and the monolayers were trypsinised (0.1\% trypsin, $0.02 \%$ EDTA) for experiments when approximately $80 \%$ confluent. For measurements of insulin secretion, MIN6 cell suspensions were maintained for 7-8 days in tissue culture flasks precoated with $1 \%(\mathrm{w} / \mathrm{v})$ bovine gelatin to allow the formation of islet-like clusters, since configuration of MIN6 cells in these three-dimensional structures markedly improves their secretory responsiveness [22]. All tissue culture reagents were purchased from Sigma Aldrich (Poole, Dorset, UK).

\section{RNA isolation and RT-PCR}

Isolated rat and human islets, HepG2 human liver carcinoma cells, MIN6 beta cells, and small pieces of mouse heart were lysed in $200 \mu \mathrm{l}$ ice-cold lysis buffer $(100 \mathrm{mmol} / \mathrm{l}$ Tris$\mathrm{HCl}, \mathrm{pH} 8.0,500 \mathrm{mmol} / \mathrm{L} \mathrm{LiCl}, 10 \mathrm{mmol} / 1 \mathrm{EDTA}, 0.1 \%[\mathrm{w} / \mathrm{v}]$ lithium dodecylsulphate, $5 \mathrm{mmol} / \mathrm{l}$ dithiothreitol) and mRNAs were isolated using a Dynabeads oligo $(\mathrm{dT})_{25}$ kit (Dynal, Oslo, Norway) according to the manufacturer's instructions. cDNAs were synthesised from each mRNA sample immediately, using Superscript II reverse transcriptase $(200 \mathrm{U})$, oligo $(\mathrm{dT})_{18}(1 \mu \mathrm{g})$ and random 10-mers $(1 \mu \mathrm{g})$ as previously described [23], and cDNAs were diluted tenfold in tRNA $(10 \mu \mathrm{g} / \mathrm{ml})$ and stored at $-85^{\circ} \mathrm{C}$. Human kidney mesangial cells, which were used as positive control tissue for human $\mathrm{AT}_{1}$ receptor expression, were obtained by collagenase digestion from donor kidneys that were unsuitable for transplantation [24] and mesangial cell cDNA was prepared as described previously [25]. Hot-start PCR amplification was performed using synthetic oligonucleotide primers specific for human AGT and ACE, and for human and rodent $\mathrm{AT}_{1}$ receptors (Molecular Biology Unit, King's College, London, UK) in 40-cycle reactions. In all PCR experiments, the presence of possible contaminants was checked by control reactions in which amplification was performed in reaction mixtures without a DNA template. No products were detected under these circumstances.

RT-PCR amplification of mRNA isolated from single human islet cells was conducted using a modification of a previously described protocol [26]. Hand-picked human islets (100) were dispersed into cell suspensions by trypsinisation, pelleted by centrifugation $(1000 \times g, 5 \mathrm{~min})$, washed twice in PBS containing $1 \mathrm{mmol} / 1$ glucose and resuspended in $500 \mu \mathrm{l}$ CMRL medium supplemented with $10 \%$ FCS. Extracellular mRNA released from damaged cells was digested by incubation $\left(15 \mathrm{~min}, 37^{\circ} \mathrm{C}\right)$ in the 
presence of $50 \mu \mathrm{g} / \mathrm{ml} \mathrm{RNase} \mathrm{A,} \mathrm{and} \mathrm{individual} \mathrm{islet} \mathrm{cells}$ were selected under an inverted phase-contrast microscope: each single cell was drawn into a microcapillary filled with PBS and washed by serial transfer through four separate drops of PBS. Each cell was further washed twice using a second microcapillary, then transferred to a $0.2-\mathrm{ml}$ PCR tube containing $5 \mu$ lysis buffer composed of $0.8 \%$ Nonidet $\mathrm{P}-40,100 \mu \mathrm{g} / \mathrm{ml}$ yeast tRNA, $40 \mathrm{U}$ rRNasin and $10 \mathrm{mmol} / \mathrm{l}$ dithiothreitol. To ensure that RT-PCR products were not derived from nucleic acids released from damaged cells, $0.5 \mu \mathrm{l}$ of the last wash drop of PBS was also used as a template for reverse transcription. Reverse transcription was performed $\left(50 \mathrm{~min}, 42^{\circ} \mathrm{C}\right)$ using $50 \mathrm{pmol}$ oligo $(\mathrm{dT})_{18}$, 100 pmol of the outer downstream primers, $200 \mathrm{U}$ MMLV reverse transcriptase, $500 \mu \mathrm{mol} / \mathrm{l}$ of each dNTP and $10 \mathrm{mmol} / \mathrm{l}$ dithiothreitol in a final volume of $20 \mu \mathrm{l} . \mathrm{AT}_{1}$ receptor and preproinsulin, preproglucagon and preprosomatostatin cDNAs were amplified separately from $5 \mu$ of the products of the RT reaction by addition of $40 \mu \mathrm{l}$ of PCR reaction mixture containing $0.5 \mu \mathrm{mol} / 1$ of the specific outer upstream primers and $2.5 \mathrm{U}$ Taq polymerase. The firstround PCR was performed for 45 cycles, after which $2 \mu$ of the PCR product were added to $28 \mu \mathrm{l}$ of a second PCR reaction mixture containing $125 \mu \mathrm{mol} / 1$ of each dNTP, $1 \mu \mathrm{mol} / 1$ of each inner primer and $1.5 \mathrm{U}$ of Taq polymerase, and the second amplification was performed for 40 cycles. In single-cell PCR experiments, control reactions, in which mRNA was used instead of a DNA template, were used to check that genomic contamination could not contribute to product synthesis.

Primer sequences, $\mathrm{MgCl}_{2}$ concentrations and PCR parameters for $\mathrm{AGT}, \mathrm{ACE}, \mathrm{AT}_{1}$ receptor, preproglucagon, preproinsulin and preprosomatostatin amplification are shown in Table 1. The PCR products were separated on $2 \%$ agarose gels containing ethidium bromide $(10 \mu \mathrm{g} / \mathrm{ml})$.
The products were excised from the gels using the Qiagen Gel Extraction kit (Qiagen, West Sussex, UK), according to the manufacturer's protocol, and their identities were confirmed by sequencing using fluorescent di-deoxy termination methods (Molecular Biology Unit, King's College London).

\section{Protein extraction and western blotting}

MIN6 cells were detached from tissue culture flasks using $0.02 \%(\mathrm{w} / \mathrm{v})$ EDTA solution to avoid proteolytic damage to cell surface proteins. Extracts of MIN6 cells and of mouse heart and kidney and of human islets and kidney mesangial cells were prepared in lysis buffer, protein contents were determined by the Bradford assay [27] and proteins were fractionated by electrophoresis on $10 \%$ polyacrylamide Bis-Tris gels (Invitrogen, Paisley, UK). Proteins were transferred to polyvinylidene fluoride membranes and $\mathrm{AT}_{1}$ receptor expression was identified by immunoprobing with $0.08 \mu \mathrm{g} / \mathrm{ml}$ of a rabbit polyclonal antibody raised against a peptide mapping near the amino terminus of the $\mathrm{AT}_{1}$ receptor (Autogen Bioclear, Calne, UK) and a 1:5,000 dilution of horseradish-peroxidase-linked goat anti-rabbit secondary antibody (DakoCytomation, Cambs, UK). Blots were developed using the ECL Western Blotting Detection Kit (GE Healthcare, Bucks, UK) and standard curves were constructed of distances migrated by Rainbow Molecular Mass Markers (GE Healthcare).

Single-cell calcium microfluorimetry

Hand-picked human islets isolated with Liberase (Roche Diagnostics, East Sussex, UK) were gently dissociated by

Table 1 Primer sequences, annealing temperatures and $\mathrm{MgCl}_{2}$ concentrations for amplification of rodent and human angiotensin type 1 receptor $\left(\mathrm{AT}_{1}\right) \mathrm{cDNAs}$, and human angiotensin converting enzyme (ACE), angiotensinogen (AGT), preproglucagon (PPG), preproinsulin (PPI) and preprosomatostatin (PPS) cDNAs

\begin{tabular}{|c|c|c|c|}
\hline cDNA amplified & Primer sequence & Annealing temp. $\left({ }^{\circ} \mathrm{C}\right)$ & $\mathrm{MgCl}_{2}(\mathrm{mmol} / \mathrm{l})$ \\
\hline Rodent $\mathrm{AT}_{1}$ receptor & (F): 5'-cagcttggtggtgattgtc-3' (R): 5'-gccatcggtattccatagc-3' & 52 & 1.0 \\
\hline Human ACE & (F): 5'-caccacagagaccagcaaga-3' (R): 5'-tcgggtaaaactggaggatg-3' & 60 & 1.5 \\
\hline Human AGT & (F): 5'-gaactggatgttgctgctga-3' (R): 5'-agaggcatagtgaggctgga-3' & 60 & 1.5 \\
\hline \multicolumn{4}{|l|}{ Human $\mathrm{AT}_{1}$ receptor } \\
\hline Outer & (F): 5'-ccttcgacgcacaatgcttg-3' (R): 5'-agccctatcggaagggttga-3' & 54 & 2.0 \\
\hline Inner & (F): 5'-ccaaagtcacctgcatcatc-3' (R): 5'-gggttgaattttgggactca-3' & 60 & 1.5 \\
\hline \multicolumn{4}{|l|}{ Human PPI } \\
\hline Outer & (F): 5'-ccctctggggacctgacc-3' (R): 5'-acaatgccacgcttctgc-3' & 56 & 1.5 \\
\hline Inner & (F): 5'-aacgaggcttcttctacacac-3' (R): 5'-ggtacagcattgttccaca-3' & 56 & 1.5 \\
\hline \multicolumn{4}{|l|}{ Human PPG } \\
\hline Outer & (F): 5'-ccaggcagacccactcag-3' (R): 5'-ttcaacaatggcgacctc-3' & 56 & 1.5 \\
\hline Inner & (F): 5'-cattcacagggcacattcac-3' (R): 5'-gcttggccttccaaataag-3' & 56 & 1.5 \\
\hline \multicolumn{4}{|l|}{ Human PPS } \\
\hline Outer & (F): 5'-cccagactccgtcagtttc-3' (R): 5'-gcctcatttcatcctgctc-3' & 56 & 1.5 \\
\hline Inner & (F): 5'-gactccgtcagtttctgca-3' (R): 5'-gcatcattctccgtctggtt-3' & 56 & 1.5 \\
\hline
\end{tabular}


trituration in a $0.02 \%$ EDTA $(\mathrm{w} / \mathrm{v})$ solution and cells were seeded onto poly-D-lysine-coated glass coverslips, and MIN6 cells were trypsinised and seeded onto 3-aminopropyltriethoxysilane-coated glass coverslips. After maintenance overnight under standard tissue culture conditions, human islet cells and MIN6 cells were loaded for $30 \mathrm{~min}$ at $37^{\circ} \mathrm{C}$ with $2.5 \mu \mathrm{mol} / 1$ of the $\mathrm{Ca}^{2+}$-fluorophore Fura-2/AM. The coverslips were placed in a steel chamber that was mounted into a heating platform on the stage of an Axiovert 135 Research Inverted microscope (Carl Zeiss, Herts, UK) and changes in intracellular $\mathrm{Ca}^{2+}$ were determined as described previously [21,28].

\section{Dynamic measurement of insulin secretion}

Groups of 100 Liberase-isolated human islets or approximately 1,000 MIN6 cell clusters were transferred to Swinnex chambers (Millipore UK, Watford, UK) containing $1-\mu \mathrm{m}$ pore-size nylon filters and perifused at a flow rate of $0.5 \mathrm{ml} / \mathrm{min}$ at $37^{\circ} \mathrm{C}$ in a temperature-controlled environment. Perifusate samples were collected every 2 min for the duration of the experiments and insulin secretion was determined by RIA [29].

\section{Data analysis}

Mean changes in cytosolic calcium are expressed as $340 / 380 \mathrm{~nm}$ ratiometric data \pm SEM or as basal-to-peak fluorescence+SEM. Insulin secretion data are expressed as a percentage of basal insulin secretion at $2 \mathrm{mmol} / 1$ glucose. Student's $t$-tests were used to assess statistical significance between treatments: differences were considered statistically significant at $p<0.05$.

\section{Results}

$\mathrm{AGT}, \mathrm{ACE}$ and $\mathrm{AT}_{1}$ receptor mRNA expression

PCR amplifications using primers for human $A G T$, the precursor of angiotensin I, produced a single product of $327 \mathrm{bp}$ from human islet cDNA, as well as from the HepG2 human liver cell line, which was used as a positive control (Fig.1a). In addition, human islets also expressed mRNA for ACE, the enzyme responsible for conversion of angiotensin I to angiotensin II (Fig.1b). Reactions using rodent and human $\mathrm{AT}_{1}$ receptor primers produced a single product of $146 \mathrm{bp}$ from mouse islet cDNA, as well as from

b

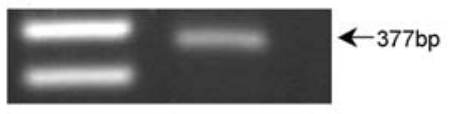

Islets

d

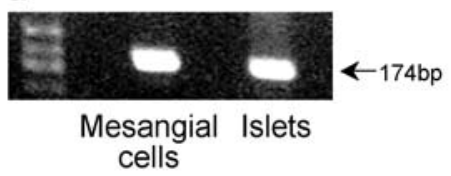

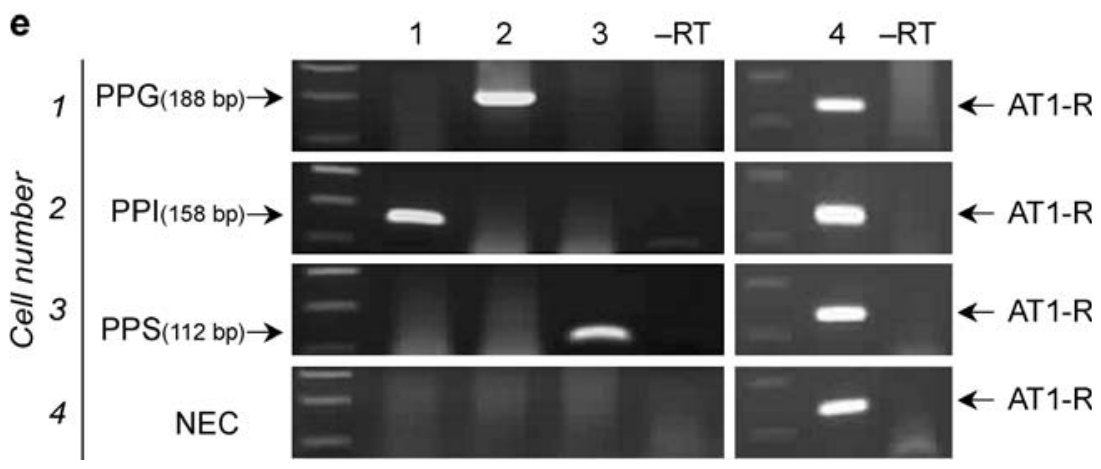

Fig. 1 Angiotensinogen, angiotensin-converting enzyme and $\mathrm{AT}_{1}$ receptor mRNA expression. Standard RT-PCR was performed for human angiotensinogen (a), human angiotensin-converting enzyme (b), rodent $\mathrm{AT}_{1}$ receptor (c) and human $\mathrm{AT}_{1}$ receptor (d) using RNA extracted from human islets (a, b, d), HepG2 human liver cells (a), mouse heart, mouse islets and MIN6 cells (c) and from human kidney mesangial cells (d). e PCR amplifications from single dispersed human islet alpha, beta or delta cells or from non- endocrine cells $(N E C)$. The islet endocrine cells were identified by reactions using primers for preproinsulin (PPI, lane 1), preproglucagon $(P P G$, lane 2) and preprosomatostatin (PPS, lane 3). Cells that did not express PPG, PPI or PPS were designated NECS (row 4). Lane 4 shows $\mathrm{AT}_{1}$ receptor $(A T 1-R)$ mRNA expression. $-R T$ indicates the absence of product formation when using an mRNA template in the absence of reverse transcriptase 
mouse heart cDNA, which is known to express the $\mathrm{AT}_{1}$ receptor subtype (Fig. 1c). A similar product was also amplified from MIN6 cell cDNA (Fig. 1c), demonstrating the expression of $\mathrm{AT}_{1}$ receptor mRNA in a pure beta cell population. A single PCR product of $174 \mathrm{bp}$ was amplified from human islet cDNA and also from human kidney mesangial cell cDNA, which is known to express this receptor subtype (Fig. 1d). Single-cell PCR reactions identified $\mathrm{AT}_{1}$ receptor mRNA expression in human beta cells, and also in human alpha and delta cells, as shown by the coexpression of mRNAs for preproinsulin, preproglucagon and preprosomatostatin and the $\mathrm{AT}_{1}$ receptor (Fig. 1e). Human islet cells that did not express mRNAs for preproinsulin, preproglucagon or preprosomatostatin were designated 'non-endocrine cells', and $\mathrm{AT}_{1}$ receptor mRNA was also amplified from these cells (Fig. 1e). In all, $\mathrm{AT}_{1}$ receptor mRNA was amplified from one of five alpha cells, four of six beta cells, two of five delta cells and two of seven non-endocrine cells. Purification and sequencing of rodent and human PCR reaction products indicated that they showed $100 \%$ homology with the expected $\mathrm{AT}_{1}$ receptor cDNAs.

\section{$\mathrm{AT}_{1}$ receptor protein expression}

Expression of $\mathrm{AT}_{1}$ receptors at the protein level was identified by western blotting using a polyclonal anti$\mathrm{AT}_{1}$ receptor antibody. A major immunoreactive protein of $\sim 42.5 \mathrm{kDa}$ was detected in mouse kidney and heart samples, as expected (Fig. 2a). A protein of the appropriate size was also detected in MIN6 cell extracts, indicating that the $\mathrm{AT}_{1}$ receptor protein is localised to mouse pancreatic beta cells. Western blot analysis with the human mesangial and islet cell extracts revealed a major immunoreactive protein of $\sim 42.5 \mathrm{kDa}$, corresponding to the $\mathrm{AT}_{1}$ receptor (Fig. $2 \mathrm{~b}$ ).

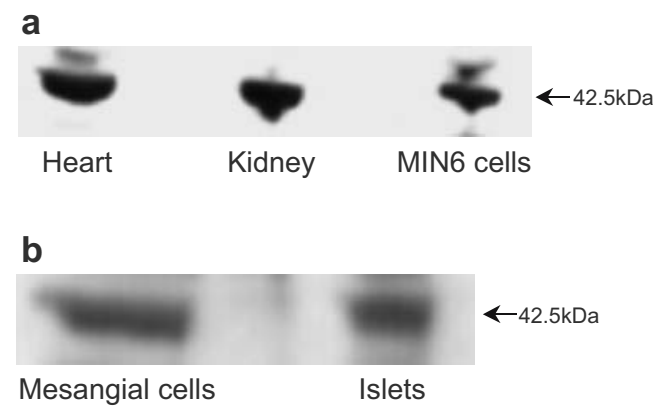

Fig. $2 \mathrm{AT}_{1}$ receptor protein expression. Western blotting was performed on fractionated samples of mouse heart, kidney and MIN6 cells (a) and human kidney mesangial cells and human islets (b) using a polyclonal antibody directed against the $\mathrm{AT}_{1}$ receptor and a horseradish-peroxidase-labelled secondary antibody
Effects of Ang II receptor activation on intracellular calcium concentration

The functional consequences of Ang II receptor activation were initially investigated by examining the effects of the stable Ang II analogue hypertensin (HT) on changes in intracellular calcium concentrations $\left(\left[\mathrm{Ca}^{2+}\right]_{\mathrm{i}}\right)$ in MIN6 cells and dispersed human islet cells. As shown in Fig. 3a, perifusion of Fura-2-loaded MIN6 cells with the Ang II amide HT $(100 \mathrm{nmol} / \mathrm{l})$ evoked a rapid elevation in $\left[\mathrm{Ca}^{2+}\right]_{\mathrm{i}}$, with a mean basal-to-peak amplitude that was $\sim 50 \%$ of the response evoked by $100 \mu \mathrm{mol} / 1$ tolbutamide, a blocker of ATP-sensitive $\mathrm{K}^{+}$channels. Figure $3 \mathrm{~b}$ shows the cumulative results of several experiments, demonstrating that the effects of HT were concentration dependent, with $22 \%$ of MIN6 cells responding to $1 \mathrm{nmol} / \mathrm{HT}$, increasing to $44 \%$ at $10 \mathrm{nmol} / 1 \mathrm{HT}$. A further tenfold increase in HT $(100 \mathrm{nmol} / \mathrm{l})$, produced a small increase in the proportion of cells showing a HT-evoked change in $\left[\mathrm{Ca}^{2+}\right]_{\mathrm{i}}(62 \%$; 55 of 89 cells from five separate experiments), and caused a significant $(p<0.001)$ increase in the amplitude of the response. As expected, MIN6 cells showed robust increases in $\left[\mathrm{Ca}^{2+}\right]_{\mathrm{i}}$ in response to either tolbutamide $(100 \mu \mathrm{mol} / \mathrm{l})$ or direct depolarisation by $\mathrm{KCl}(20 \mathrm{mmol} / \mathrm{l}$, Fig. 3b). Similar effects were observed in experiments using human beta cells, as shown in Fig. 3c. Tolbutamide $(100 \mu \mathrm{mol} / \mathrm{l})$ and $\mathrm{KCl}$ $(20 \mathrm{mmol} / \mathrm{l})$ increased $\left[\mathrm{Ca}^{2+}\right]_{\mathrm{i}}$ in human islet cells, and the tolbutamide-responsive cells were considered to be beta cells and were subsequently challenged with HT $(1,10$ and $100 \mathrm{nmol} / \mathrm{l})$. In all, $67 \%$ of tolbutamide-responsive cells showed an increase in cytosolic $\mathrm{Ca}^{2+}$ in response to $10 \mathrm{nmol} / \mathrm{l} \mathrm{HT}$, while all tolbutamide-responsive cells showed an increase in $\left[\mathrm{Ca}^{2+}\right]_{\mathrm{i}}$ at $100 \mathrm{nmol} / 1$ HT (Fig. 3c).

A non-selective Ang II receptor antagonist (saralasin) and an $\mathrm{AT}_{2}$ receptor-specific antagonist (PD123319) were used to identify the Ang II receptor subtype involved in the effects of HT on $\left[\mathrm{Ca}^{2+}\right]_{i}$ in beta cells. As shown in Fig. 4a, the addition of $100 \mathrm{nmol} / \mathrm{l} \mathrm{HT}$ in the presence of $1 \mu \mathrm{mol} / 1$ saralasin resulted in only a small increase in $\left[\mathrm{Ca}^{2+}\right]_{\mathrm{i}}$. However, upon removal of saralasin, HT elicited a rapid and reversible increase in $\left[\mathrm{Ca}^{2+}\right]_{\mathrm{i}}$. Similar effects were seen in experiments using tolbutamide-sensitive dispersed human islet cells, as shown in Fig. 4b, demonstrating AT-receptormediated effects of $\mathrm{HT}$ on $\left[\mathrm{Ca}^{2+}\right]_{\mathrm{i}}$ in both primary human beta cells and MIN6 cells. In contrast, selective blockade of the $\mathrm{AT}_{2}$ receptor in tolbutamide-sensitive human beta cells by the presence of PD123319 ( $1 \mu \mathrm{mol} / \mathrm{l})$ did not significantly reduce HT-stimulated increases in $\left[\mathrm{Ca}^{2+}\right]_{\mathrm{i}}$ (Fig. 4c).

HT-induced increases in $\left[\mathrm{Ca}^{2+}\right]_{\mathrm{i}}$ in MIN6 cells were partially reduced by the L-type $\mathrm{Ca}^{2+}$ channel blocker, nifedipine. Figure 5 shows that exposure of cells to nifedipine $(10 \mu \mathrm{mol} / 1)$ alone did not affect basal $\left[\mathrm{Ca}^{2+}\right]_{\mathrm{i}}$ and that HT $(100 \mathrm{nmol} / \mathrm{l})$ caused a marked elevation in $\left[\mathrm{Ca}^{2+}\right]_{i}$ in the absence of nifedipine. However, the concomitant application of nifedipine $(10 \mu \mathrm{mol} / \mathrm{l})$ significantly inhibited the 
Fig. 3 Changes in intracellular calcium in Fura-2-loaded beta cells. a Trace from a single Fura2-loaded MIN6 cell. Mean+ SEM basal-peak fluorescence data for $\mathbf{b}$ MIN6 cells $(n=16)$ and $\mathbf{c}$ human islet beta cells $(n=6)$ a

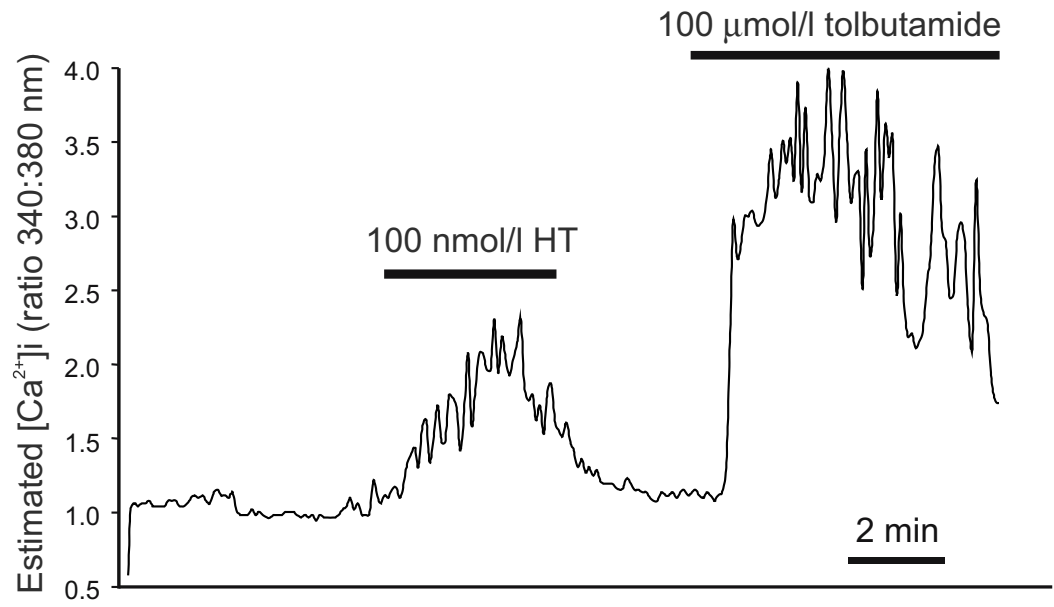

b

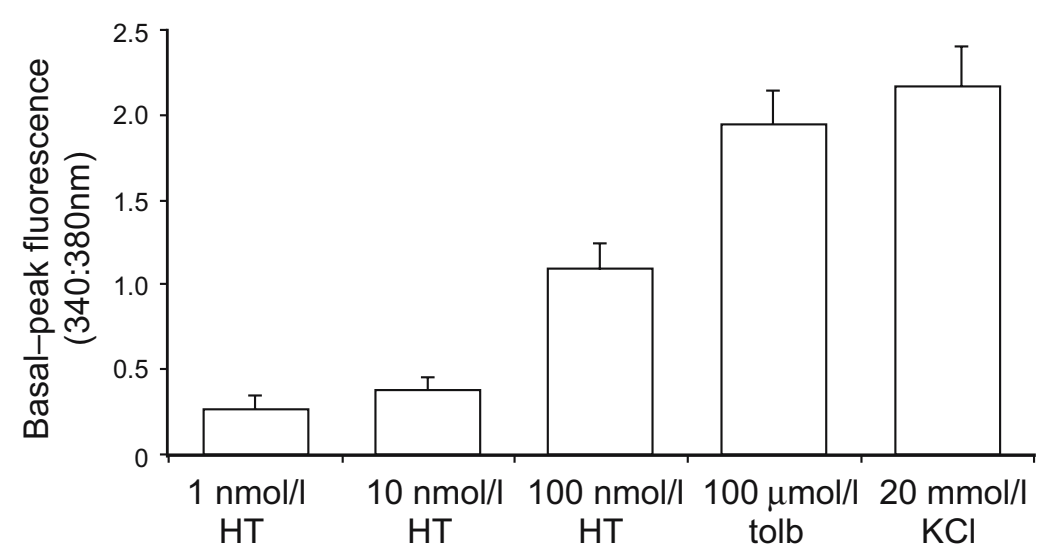

C

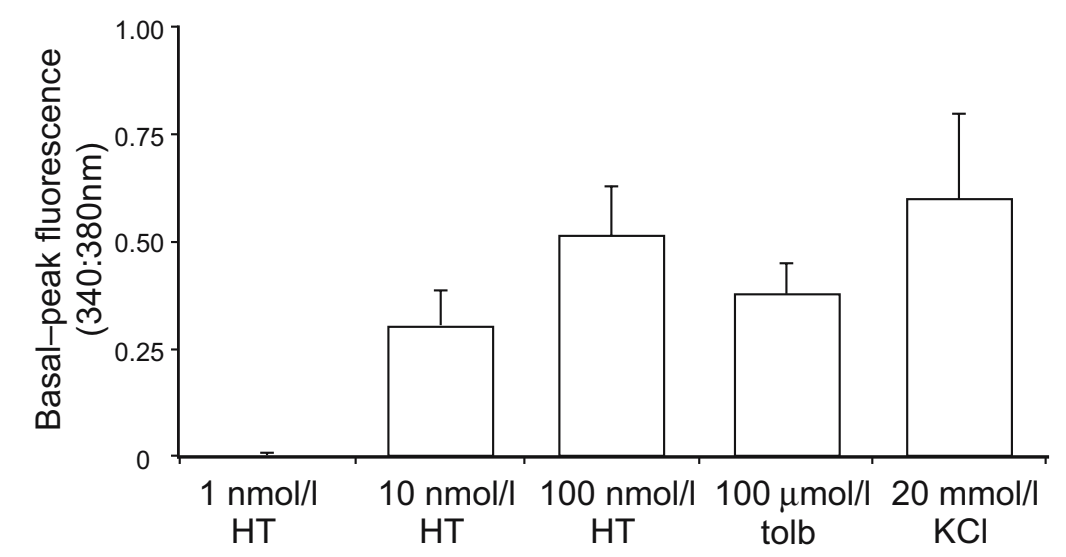

effects of HT on $\left[\mathrm{Ca}^{2+}\right]_{i}$, although there was a sustained plateau above basal fluorescence. Subsequent removal of nifedipine resulted in an immediate and rapid increase in $\left[\mathrm{Ca}^{2+}\right]_{i}$, with a more enhanced $\mathrm{Ca}^{2+}$ peak than had been obtained on the first exposure to HT. HT-induced increases in $\left[\mathrm{Ca}^{2+}\right]_{\mathrm{i}}$ in MIN6 cells were also partially inhibited by the presence of the phospholipase C (PLC) inhibitor, U73122. Thus the HT-induced increase in Fura-2 fluorescence (100 nmol/1, basal-to-peak fluorescence ratio $0.90 \pm 0.07$ ) was significantly reduced in the same cells by the presence of U73122 (10 $\mu \mathrm{mol} / 1,0.50 \pm 0.03, p<0.01, n=15)$. 

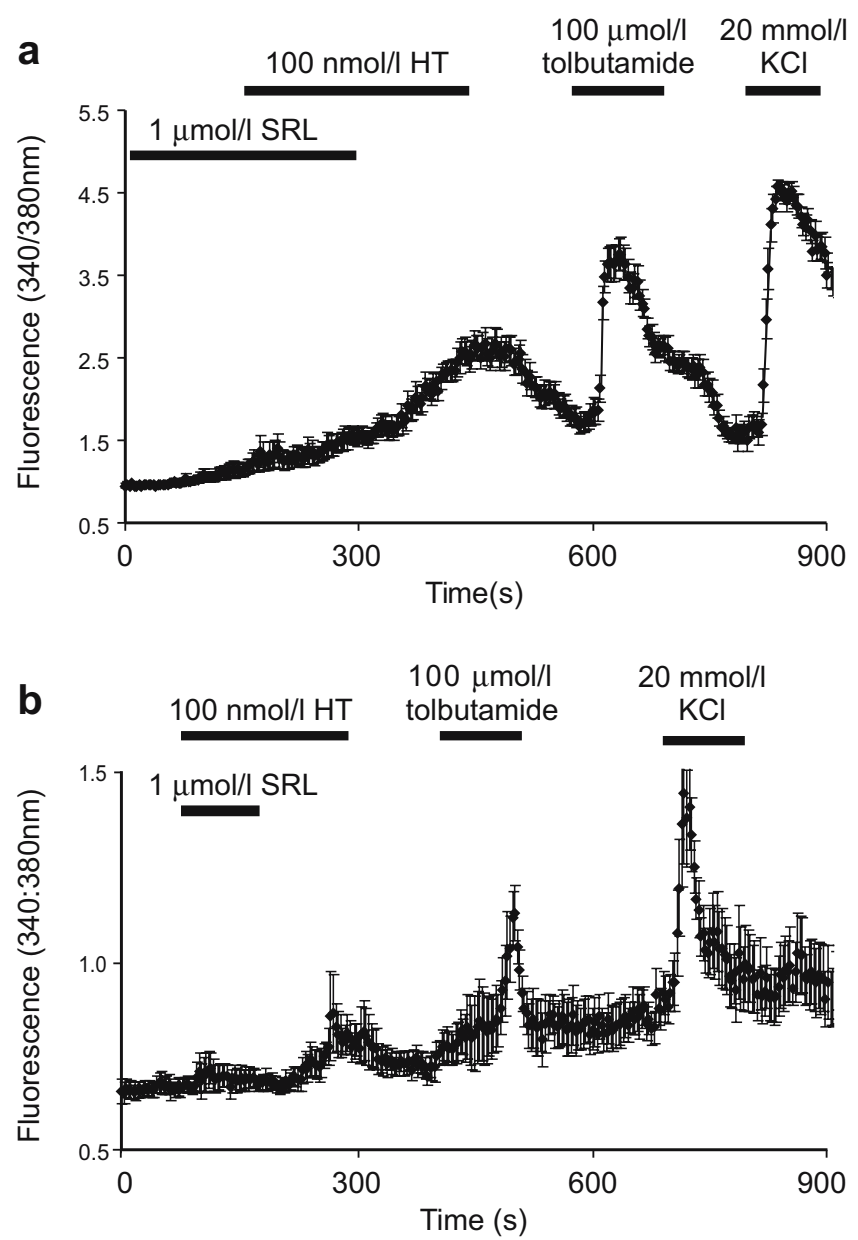

C

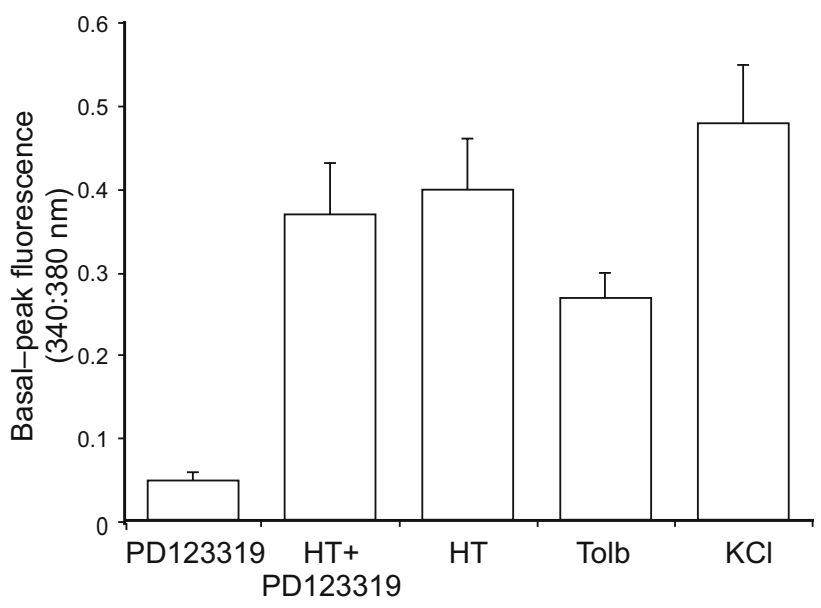

Fig. 4 Effect of AT receptor antagonists on intracellular calcium. Mean \pm SEM fluorescence traces from Fura-2-loaded MIN6 cells $(n=16)$ (a) and from b human islet beta cells $(n=4)$ showing the effects of hypertensin $(H T)$ in the presence of saralasin $(S R L)$. c Mean basal-peak fluorescence data (+SEM, $n=17-22)$ of the effects of PD123319 in human islet beta cells

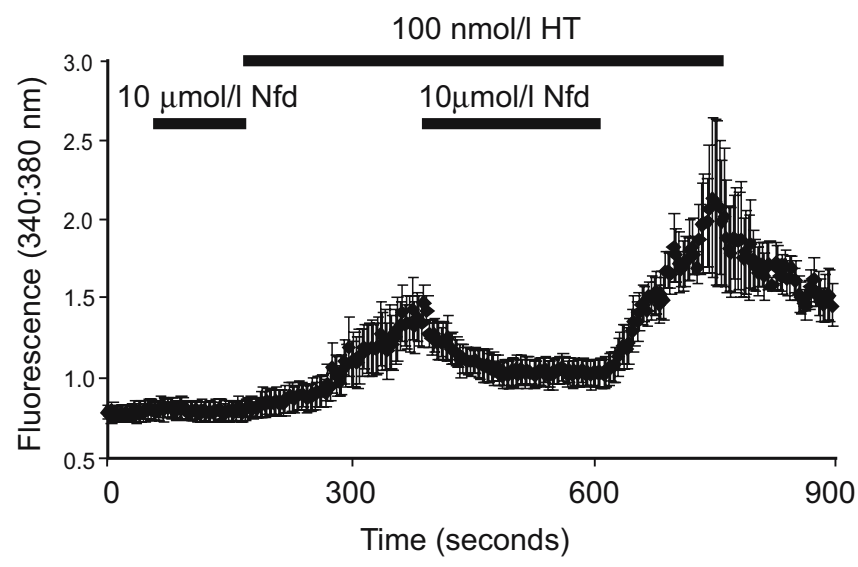

Fig. 5 Effect of nifedipine (Nfd) on intracellular calcium. Mean \pm SEM fluorescence traces from Fura-2-loaded MIN6 cells showing the effects of Nfd on hypertensin-stimulated increases in calcium $(n=4)$

Effects of Ang II receptor activation on insulin secretion

Perifusion experiments demonstrated that insulin secretion, as expected, was significantly $(p<0.001)$ stimulated upon raising the glucose concentration from 2 to $8 \mathrm{mmol} / \mathrm{l}$ in isolated human islets (Fig. 6a) and MIN6 cell clusters (Fig. 6b). The insulin secretory response to glucose $(8 \mathrm{mmol} / \mathrm{l})$ was significantly $(p<0.05)$ potentiated by the addition of Ang II (100 nmol/l) during the plateau phase of the glucose-induced response (Fig. 6a,b). The responses to Ang II were rapidly reversible on removal of Ang II from the perifusion medium, resulting in a restoration of insulin output to levels equivalent to the sustained secondary phase plateau of glucose-induced secretion. Both human islets and MIN6 cell clusters also responded to a subsequent exposure to HT $(100 \mathrm{nmol} / \mathrm{l})$ with a rapid increase in insulin secretion. Human islets showed similar responses to Ang II and HT (Fig. 6a), whereas glucose-induced secretion was enhanced to a greater extent by HT in the MIN6 clusters (Fig. 6b). In similar perifusion experiments an elevation in the glucose concentration from 2 to $16.7 \mathrm{mmol} / 1$ resulted in a maximal 10.6-fold increase in insulin secretion, followed by a secondary plateau phase of $187 \pm 64 \%$ of basal. Ang II also significantly potentiated insulin secretion from human islets in the presence of $16.7 \mathrm{mmol} / \mathrm{l}$ glucose, further increasing secretion to $406 \pm 110 \%$ of basal (means \pm SEM, $n=4, p<0.05)$.

Activating the $\mathrm{AT}_{1}$ receptor also exerted stimulatory effects on insulin secretion at a sub-stimulatory concentration of glucose $(2 \mathrm{mmol} / \mathrm{l})$. Thus, Ang II $(100 \mathrm{nmol} / \mathrm{l})$ provoked a rapid increase in insulin release from human islets (Fig. 6c) and from MIN6 cell clusters (Fig. 6d) and the secretory response was followed by a steady decline in secretion, despite the continued presence of Ang II. Secretion levels were restored to basal when islets and MIN6 

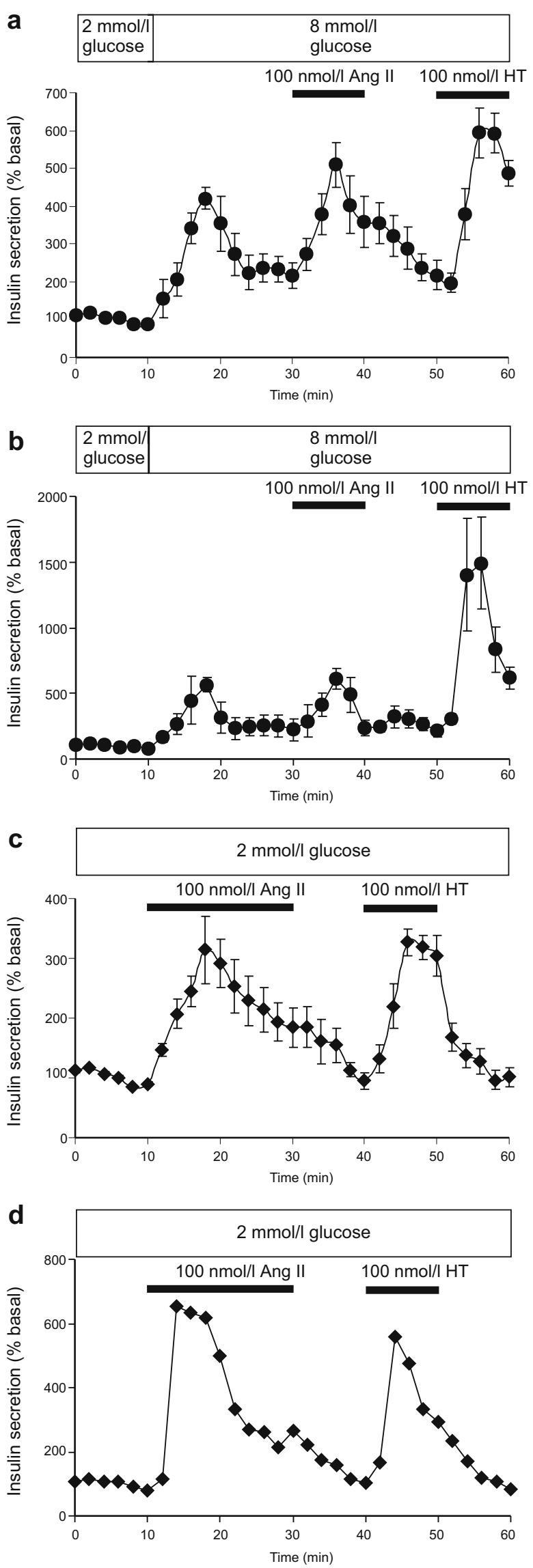

Fig. 6 Insulin secretion from perifused human islets and MIN6 cell clusters. Isolated human islets $(\mathbf{a}, \mathbf{c})$ and MIN6 cell clusters $(\mathbf{b}, \mathbf{d})$ were perifused with media supplemented with the agents shown by the horizontal bars (Ang II angiotensin II; HT hypertensin) and insulin secretion was measured every 2 min by RIA. Data are from two to four separate perifusion chambers of islets from a single isolation and are expressed $\mathbf{a}-\mathbf{c}$ as means \pm SEM $(n=4)$ and $\mathbf{d}$ as means $(n=2)$

cell clusters were perifused with $2 \mathrm{mmol} / \mathrm{l}$ glucose in the absence of Ang II (time $=30-40 \mathrm{~min}$ ). Subsequent exposure to HT $(100 \mathrm{nmol} / \mathrm{l})$ also initiated a rapid and transient increase in basal insulin secretion, of similar amplitude to that obtained with $100 \mathrm{nmol} / \mathrm{l}$ Ang II (Fig. 6c,d). The effects of Ang II and HT were not additive, since simultaneous exposure to both agonists did not cause significant enhancement of the secretory response to the individual agonists (secretion, $\% 2 \mathrm{mmol} / \mathrm{l}$ glucose: $100 \mathrm{nmol} / \mathrm{l}$ Ang II: 195 $\pm 43 ; 100 \mathrm{nmol} / 1 \mathrm{HT}: 200 \pm 59 ; 100 \mathrm{nmol} / 1 \mathrm{Ang}$ II+ $100 \mathrm{nmol} / 1$ HT: $224 \pm 75$, means \pm SEM, $n=4$, NS). The presence of nifedipine $(10 \mu \mathrm{mol} / \mathrm{l})$ reduced Ang II (100 nmol/l)-stimulated insulin secretion at $2 \mathrm{mmol} / \mathrm{l}$ glucose by $38.8 \pm 8 \%(p<0.01)$, indicating that the effects of Ang II were only partially dependent on $\mathrm{Ca}^{2+}$ influx through voltage-operated $\mathrm{Ca}^{2+}$ channels.

\section{Discussion}

In the systemic RAS, circulating renin cleaves Ang I from AGT, which is synthesised by the liver, and endothelial cells of the lung produce ACE to convert Ang I to Ang II. There is convincing evidence of an intrinsic pancreatic RAS, through which Ang II is produced locally [7-11, 30 32], but the physiological roles of this system remain unclear. The present results demonstrate unambiguously that human islets of Langerhans express both AGT and ACE, suggesting that the islets themselves may produce Ang II locally. Furthermore, receptors for Ang II were detected in human islets, and our use of single-cell RT-PCR to amplify mRNA from individual human islet cells demonstrates for the first time that primary human islet beta cells express the $\mathrm{AT}_{1}$ receptor mRNA. Our identification of $\mathrm{AT}_{1}$ receptor expression in human and mouse beta cells is consistent with previous reports suggesting expression of $\mathrm{AT}_{1}$ receptors in dog [8], mouse [30], rat [31] and human [32] pancreas and in isolated mouse islets [11], and our study further indicates that alpha, delta and human islet non-endocrine cells also express $\mathrm{AT}_{1}$ receptors. Our detection of $\mathrm{AT}_{1}$ receptor mRNA and protein in human beta cells and mouse MIN6 cells is also consistent with our results using AT receptor antagonists, which demonstrated the presence of a functional $\mathrm{AT}_{1}$ receptor subtype coupled to elevations in beta cell $\left[\mathrm{Ca}^{2+}\right]_{i}$, in agreement with previous pharmacological studies in which $\mathrm{AT}_{1}$ receptor activation was associated with $\mathrm{Ca}^{2+}$ transients in a number of other tissues [33-37].

Plasma membrane $\mathrm{Ca}^{2+}$ channels, including L-type $\mathrm{Ca}^{2+}$ channels, are known to play important roles in Ang IIinduced cellular responses $[38,39]$, and our observation 
that an L-type $\mathrm{Ca}^{2+}$ channel blocker reversibly inhibited Ang II-stimulated increases in beta cell $\left[\mathrm{Ca}^{2+}\right]_{\mathrm{i}}$ suggests that this mechanism is operational in beta cells. However, blockade of L-type $\mathrm{Ca}^{2+}$ channels was only partially effective in blocking $\mathrm{AT}_{1}$-induced increases in $\left[\mathrm{Ca}^{2+}\right]_{\mathrm{i}}$, suggesting the existence of another mechanism. Activation of the PLC-inositol trisphosphate $\left(\mathrm{IP}_{3}\right)$ signalling pathway is involved in the rapid Ang II-evoked changes in $\left[\mathrm{Ca}^{2+}\right]_{\mathrm{i}}$ in a number of other cell types [40-43]. The inhibition of HTinduced elevations in $\left[\mathrm{Ca}^{2+}\right]_{i}$ in beta cells by U73122, a PLC inhibitor, suggests that the beta cell $\mathrm{AT}_{1}$ receptor acts, at least in part, via $\mathrm{IP}_{3}$-mediated release of cytosolic $\mathrm{Ca}^{2+}$ from the endoplasmic reticulum. Our data therefore indicate that, in pancreatic beta cells, $\mathrm{AT}_{1}$ receptor activation increases $\left[\mathrm{Ca}^{2+}\right]_{\mathrm{i}}$ both by promoting influx of extracellular $\mathrm{Ca}^{2+}$ and by the PLC-mediated $\mathrm{IP}_{3}$-sensitive release of $\mathrm{Ca}^{2+}$ release from intracellular stores.

Changes in $\left[\mathrm{Ca}^{2+}\right]_{\text {i }}$ play a fundamental role in the regulation of insulin secretion, and the dual mode of action of $\mathrm{AT}_{1}$ receptor activation on beta cell $\left[\mathrm{Ca}^{2+}\right]_{\mathrm{i}}$ is consistent with the concomitant stimulation of insulin secretion from human islets and MIN6 cells. Stimulus-response coupling in beta cells is complex, but it is generally agreed that the initiation of insulin secretion by nutrient stimuli, such as glucose, is normally dependent on an influx of extracellular $\mathrm{Ca}^{2+}$ through L-type $\mathrm{Ca}^{2+}$ channels in response to depolarisation. Our experiments suggest that $\mathrm{AT}_{1}$ receptorinduced influx of extracellular $\mathrm{Ca}^{2+}$ is not the sole mechanism of action of Ang II on insulin secretion, since the increases in $\left[\mathrm{Ca}^{2+}\right]_{\mathrm{i}}$ and insulin secretion were not fully abolished by nifedipine. This is consistent with Ang II receptors being coupled to a PLC-mediated release of intracellular $\mathrm{Ca}^{2+}$, and this mechanism could also explain the enhancement by Ang II of glucose-induced insulin secretion from human islets and MIN6 cells. Receptor agonists often potentiate rather than initiate insulin secretory responses, but we have recently reported that two other agonists (17beta-oestradiol and adrenocorticotrophin) stimulate $\mathrm{Ca}^{2+}$-dependent insulin secretion from human islets at $2 \mathrm{mmol} / \mathrm{l}$ glucose [44, 45].

Irrespective of the coupling mechanism involved, our data clearly demonstrate that $\mathrm{AT}_{1}$ receptor activation stimulates insulin secretion, in contrast to previous reports. It is difficult to dissect out direct effects on Ang II on pancreatic beta cells in in vivo studies, or in those using whole perfused pancreas, but previous studies using isolated rodent islets have reported either a lack of effect [20] or an inhibitory effect [11] on insulin secretion. An observed lack of effect of Ang II may be ascribed to the loss of functional cell-surface receptors during the collagenase digestion of rat pancreas during islet preparation [20], while the inhibitory effects in mouse islets were attributed to reduced (pro)insulin biosynthesis [11]. In common with other circulating bioactive peptides, Ang II has a short halflife and our experiments were specifically designed to measure immediate and rapid effects of $\mathrm{AT}_{1}$ receptor activation on $\left[\mathrm{Ca}^{2+}\right]_{\mathrm{i}}$ and insulin secretion within a timeframe of minutes. Any inhibitory effects on insulin se- cretion as a consequence of reduced (pro)insulin synthesis in response to prolonged $\mathrm{AT}_{1}$ receptor activation would not be detected in our studies. Similarly, the present experiments were not designed to address the mechanisms underlying the reported protective effects of treatment with ACE inhibitors or Ang II receptor blockers on the incidence of type 2 diabetes [46-48], since these trials were based on many years of prolonged treatment, and the therapeutic effects may be secondary to blocking the proinflammatory effects of Ang II [49, 50]. Nonetheless, our study identifies the human beta cell as one potential target of pharmacological manipulation of the RAS.

The circulating concentration of Ang II is approximately $5 \mathrm{pmol} / 1$ in healthy individuals [51], considerably lower than the concentrations that stimulated insulin secretion in these studies. However, concentrations of locally produced Ang II would be expected to exceed systemic concentrations and may achieve the concentration range used in the current studies, although accurate quantification of tissue concentrations of Ang II is hampered by its short half-life $[8,11]$. Our observations are therefore consistent with an intrinsic pancreatic RAS generating high, but localised, concentrations of Ang II, which has a short-lived and direct stimulatory effect on beta cells to promote insulin secretion. Cells within islets show coordinated responses [52], and it is an intriguing possibility that the local production of Ang II may be important in regulating a coordinated insulin secretory response from pancreatic beta cells.

Acknowledgements We gratefully acknowledge Guy's and St Thomas' Charity, The Eli Lilly International Foundation and The European Foundation for the Study of Diabetes for grant support. We are grateful to Ms H. Mandefield, the transplantation coordinators of South-Thames and King's College Hospital and relatives of the organ donors for human pancreases. We thank Y. Oka and J. I. Miyazaki (University of Osaka, Japan) for provision of the MIN6 cells, L. Gnudi (King's College London) for human mesangial cell cDNA and protein extracts, and $\mathrm{H}$. Asare-Anane for assistance with perifusions and RIAs.

\section{References}

1. Gallinat S, Busche S, Raizada MK, Sumners C (2000) The angiotensin II type 2 receptor: an enigma with multiple variations. Am J Physiol Endocrinol Metab 278:E357-E374

2. De Gasparo $M$, Catt KJ, Inagami $T$, Wright JW, Unger $T H$ (2000) The angiotensin II receptors. Pharmacol Rev 52:415-472

3. Hojima Y, Yamashita N, Ochi N, Moriwaki C, Moriya H (1977) Isolation and properties of dog and rat pancreatic kallikreins. J Biochem 81:599-610

4. Arakawa K (1996) Serine protease angiotensin II systems. J Hypertens 14 (Suppl):S3-S7

5. Shanmugam N, Llorens-Cortes C, Clauser E, Corvol P, Gasc $\mathrm{JM}$ (1995) Expression of angiotensin II $\mathrm{AT}_{2}$ receptor mRNA during development of rat kidney and adrenal gland. Am J Physiol 268:F922-F930

6. Norwood VF, Craig MR, Harris JM, Gomez RA (1997) Differential expression of angiotensin II receptors during early renal morphogenesis. Am J Physiol 272:R662-R668

7. Leung PS, Chappell MC (2003) A local pancreatic reninangiotensin system: endocrine and exocrine roles. Int J Biochem Cell Biol 35:838-846 
8. Chappell MC, Millsted A, Diz DI, Brosnihan KB, Ferrario CM (1991) Evidence for an intrinsic angiotensin system in the canine pancreas. J Hypertens 9:751-759

9. Chappell MC, Diz DI, Jacobsen DW (1992) Pharmacological characterisation of angiotensin II binding sites in the canine pancreas. Peptides 13:13-18

10. Leung PS, Carlsson PO (2001) Tissue renin-angiotensin system: its expression, localization, regulation and potential role in the pancreas. J Mol Endocrinol 26:155-164

11. Lau T, Carlsson PO, Leung PS (2004) Evidence for a local angiotensin-generating system and dose-dependent inhibition of glucose-stimulated insulin release by angiotensin II in isolated pancreatic islets. Diabetologia 47:240-248

12. National High Blood Pressure Program Working Group (1994) The national high blood pressure education program working group report on hypertension in diabetes. Hypertension 23:145-158

13. Stern S (1995) Diabetes and cardiovascular disease: The common soil hypothesis. Diabetes 44:369-374

14. Pollare T, Litchell H, Brene C (1989) A comparison of the effects of hydrochlorothiazide and captopril on glucose and lipid metabolism in patients with hypertension. N Engl J Med 321:868-873

15. Santoro D, Natali A, Polombo C et al (1992) Effects of chronic angiotensin converting enzyme inhibition on glucose tolerance and insulin sensitivity in essential hypertension. Hypertension 20:181-191

16. Haenni A, Andersson PE, Lind L, Berne C, Lithell H (1994) Electrolye changes and metabolic effects of lisinopril/bendrofluazide treatment. Results from a randomised, double-blind study with parallel groups. Am J Hypertens 7:615-622

17. Fliser D, Schaefer F, Schmid D, Veldhuis JD, Ritz E (1997) Angiotensin II affects basal, pulsatile and glucose-stimulated insulin secretion in humans. Hypertension 30:1156-1161

18. Jansson L (1994) The regulation of pancreatic islet blood flow. Diabetes Metab Rev 10:407-416

19. Carlsson PO, Berne C, Jansson L (1998) Angiotensin II and the endocrine pancreas: effects on blood islet flow and insulin secretion in rats. Diabetologia 41:127-133

20. Dunning BE, Molt JH, Fawcett CP (1984) Actions of neurohypophysial peptides on pancreatic hormone release. Am J Physiol Endocrinol Metab 246:E108-E114

21. Huang GC, Zhao M, Jones P et al (2004) The development of new density gradient media for purifying human islets and isletquality assessments. Transplantation 77:143-145

22. Hauge-Evans AC, Squires PE, Persaud SJ, Jones PM (1999) Pancreatic $\beta$-cell-to- $\beta$-cell interactions are required for integrated responses to nutrient stimuli: Enhanced $\mathrm{Ca}^{2+}$ and insulin secretory responses of MIN6 pseudoislets. Diabetes 48:1402-1408

23. Persaud SJ, Roderigo-Milne HM, Squires PE et al (2002) A key role for $\beta$-cell cytosolic phospholipase $A_{2}$ in the maintenance of insulin stores, but not in the initiation of insulin secretion. Diabetes 51:98-104

24. Gruden G, Thomas S, Burt D et al (1997) Mechanical stretch induces vascular permeability factor in human mesangial cells: mechanisms of signal transduction. Proc Natl Acad Sci USA 94:12112-12116

25. Burt DJ, Gruden G, Thomas SM et al (2003) P38 mitogenactivated protein kinase mediates hexosamine-induced TGFbeta1 mRNA expression in human mesangial cells. Diabetologia 46:531-537

26. Harbeck MC, Rothenberg PL (1995) A technique for isolating single cells for analysis by reverse transcription polymerase chain reaction. Anal Biochem 230:193-196

27. Bradford MM (1976) A rapid and sensitive method for the quantitation of microgram quantities of protein utilising the principle of protein-dye binding. Anal Biochem 72:248-254

28. Squires PE, Hauge-Evans AC, Persaud SJ, Jones PM (2000) Synchronisation of $\mathrm{Ca}^{2+}$-signals within insulin-secreting pseudoislets: effects of gap-junctional uncouplers. Cell Calcium 27:267-296
29. Jones PM, Salmon DMW, Howell SL (1988) Protein phosphorylation in electrically permeabilised islets of Langerhans: effects of $\mathrm{Ca}^{2+}$, cyclic AMP, a phorbol ester and noradrenaline. Biochem J 254:397-403

30. Leung PS, Chan HC, Wong PYD (1998) Immunohistochemical localization of angiotensin II in the mouse pancreas. Histochem J 30:21-25

31. Leung PS, Chan WP, Wong TP, Sernia C (1999) Expression and localization of the renin-angiotensin system in the rat pancreas. J Endocrinol 160:13-19

32. Tahmasebi M, Puddefoot JR, Inwang ER, Vinson GP (1999) The renin-angiotensin system in the human pancreas. J Endocrinol 161:317-322

33. Marrero MB, Schieffer B, Ma H, Bernstein KE, Ling BN (1996) Ang II-induced tyrosine phosphorylation stimulates phospholipase C-gamma 1 and chloride channels in mesangial cells. Am J Physiol Cell Physiol 270:C1834-C1842

34. Winpenny JP, Harris A, Hollingsworth MA, Argent BE, Gray MA (1998) Calcium-activated chloride conductance in a pancreatic adenocarcinoma cell line of ductal origin (HPAF) and in freshly isolated human pancreatic duct cells. Pflugers Arch 435:796-803

35. Barnhart DC, Sarasi GA, Romanchuk G, Mulholland MW (1999) Calcium signalling induced by angiotensin II in the pancreatic acinar cell line AR42J. Pancreas 18:189-196

36. Fink AS, Wang Y, Mendez T et al (2002) Angiotensin II evokes calcium-mediated signalling events in isolated dog pancreatic epithelial cells. Pancreas 25:290-295

37. Greco S, Muscella A, Elia MG, Salvatore P, Storelli C (2002) Activation of angiotensin II type I receptor promotes protein kinase $\mathrm{C}$ translocation and cell proliferation in human cultured breast epithelial cells. J Endocrinol 174:205-214

38. Zhu Z, Herbert J (1997) Calcium channels mediate angiotensin II-induced drinking behaviour and c-fos expression in the brain. Brain Res 778:206-214

39. Suarez C, Garcia-Tornadu I, Cristina C et al (2002) Angiotensin and calcium signalling in the pituitary and hypothalamus. Cell Mol Neurobiol 22:315-333

40. Smith JB (1986) Angiotensin II receptor signalling in cultured vascular smooth muscle cells. Am J Physiol 250:F759-F769

41. Garcia-Sainz JA, Macias-Silva M (1990) Angiotensin II stimulates phosphoinositide turnover and phosphorylase through AII-1 receptors in isolated rat hepatocytes. Biochem Biophys Res Commun 172:780-785

42. Gyurko R, Kimura B, Kurian P, Crews FT, Phillips MI (1992) Angiotensin II receptor subtypes play opposite roles in regulating phosphatidylinositol hydrolysis in rat skin slices. Biochem Biophys Res Commun 186:285-292

43. Poggioli J, Lazar G, Houillier P, Gardin JP, Achard JM, Paillard M (1992) Effects of angiotensin II and nonpeptide receptor antagonists on transduction pathways in rat proximal tubule. Am J Physiol Cell Physiol 263:C750-C758

44. Al-Majed HT, Persaud SJ, Jones PM, Whitehouse BJ (2005) Effect of $17 \beta$-estradiol on insulin secretion and cytosolic calcium in MIN6 mouse insulinoma cells and human islets of Langerhans. Pancreas 30:307-313

45. Al-Majed HT, Jones PM, Persaud SJ, Huang GC, Amiel SA, Whitehouse BJ (2004) ACTH stimulates insulin secretion from MIN6 cells and primary mouse and human islets of Langerhans. J Endocrinol 180:155-166

46. Hanson L, Lindholm LH, Niskanen L et al (1999) Effects of angiotensin converting enzyme inhibition compared with conventional therapy on cardiovascular mortality and morbidity in hypertension: the Captopril Prevention Project (CAPP) randomised trial. Lancet 353:611-616

47. Yusuf S, Sleight P, Pogue J, Bosch J, Davies R, Dagenais G (2000) Effects of an angiotensin-converting enzyme inhibitor, ramipril, on cardiovascular events in high-risk patients: the Heart Outcomes Prevention Evaluation Study Investigators. N Engl J Med 342:145-153 
48. Dahlof B, Devereaux RB, Kjeldsen SE et al (2002) Cardiovascular morbidity and mortality in the Losartan Intervention For Endpoints in reduction in hypertension study (LIFE): a randomised trial against atenolol. Lancet 259:995-1003

49. Wu L (2001) Roles of angiotensin II type 2 receptor stimulation associated with selective angiotensin II receptor blockade with valsartan in the improvement of inflammation-induced vascular injury. Circulation 104:2716-2721
50. Oubina MP (2002) Valsartan improves fibronolytic balance in atherosclerotic rabbits. J Hypertens 20:303-310

51. Clemson B, Gaul L, Gubin SS et al (1994) Prejunctional angiotensin II receptors: facilitation of norepinephrine release in the human forearm. J Clin Invest 93:684-691

52. Pipeleers D, In't Veld P, Maes E, Van de Winkel M (1982) Glucose-induced insulin release depends on functional cooperation between islet cells. Proc Natl Acad Sci USA 79:7322-7325 